\title{
The Influence of Credit Period and Interest Rates on the Interest of Home Ownership Credit Users in PT. PANIN Bank (PERSERO) TBK
}

\author{
Rosnaini Daga,.SE,.MM \\ STIMNitro Makassar, Indonesia \\ rosnaini.daga@nitromks.ac.id
}

\begin{abstract}
This study aims to examine the influence of credit period and interest rates on mortgages users' interest in PT. Panin Bank (Persero) Tbk. The method used in this research is multiple linear regression analysis using SPSS, which was processed based on the tabulated results of the observation sheet. From the analysis of the influence of credit period and interest rates on mortgages users' interest in PT. Panin Bank (Persero) Tbk. Makassar branch, it can be concluded that the term and interest rates have a positive effect on mortgages users' interest in the bank. The increase of the time limit will also increase the interests of customers. On the other hand, the increase of interest rates will decrease the interest of users. From these two researched variables, the most dominant variable affecting the mortgages users' interest in PT. Panin Bank (Persero) Tbk. Makassar branch is interest rates, because interest rates have the greatest $\mathrm{t}$-count compared to the t-count of credit period. Therefore, it can be proposed that one of the most dominant variables affecting the interest of the mortgages users in the bank is the interest rates.
\end{abstract}

Keywords: Credit period, term, interest rate, interest, mortgages users

\section{Introduction}

Banking sector has a strategic position as an intermediary and supporting the payment system is a crucial factor of the national economic development process. Banks are intended as an intermediary for those who have surplus funds with the underfunded. Thus, the banks will be engaged in lending activities and a variety of services. The banks serve the financing needs as well as the launch system for the development of all sectors of the economy. One of the main elements of people's welfare is the fulfillment of their needs with regard to housings. At the moment, the need for housing is a national problem, especially in urban areas. The government together with employers and the society should look for a solution. Housing development companies (Developers) as a private party involved should also find a solution to the problem of housing, as their main business activity is to build and sell housing to consumers. The purchase of a house by a consumer can be done through two systems:

- The gradual cash system, in the purchase of the house, consumers pay gradually for a period of between 6 months to 1 year;

- House ownership credit system, in this system a consumers buys a house using a credit system in which they pay within a period of 5 to 20 years.

PT. PANIN Bank (PERSERO) TBK. is one of financial institutions operating in Indonesia; it cannot be separated from the problem of competition. It is because the products offered by the bank to customers are similar. Home Loan is one of the products offered by the bank to the public. In the provision of products of credit (KPR) instruments, the bank sometimes distinguishes between house ownership credit (KPR) and service credit in terms of the interest rate and terms in order to maximize the community participation in the banking industry, particularly in the mortgage (KPR).This study addresses the following question: "What time period and interest rates affect the interest of the mortgage credit users at the PT. PANIN Bank (PERSERO) TBK ? Thus, this study analyzes the effects of the duration and mortgage rates at PT.PANIN Bank (PERSERO) TBK. 


\section{Literature Review}

Understanding Credit: According to the Banking Law number 10 of 1998 , credit is the provision of funds or equivalent claims based on a lending agreement or contract between the bank and other parties which requires the borrower to pay off the debt after a certain period of time with interest .Meanwhile, according to Malay (2002: 87), the third-party funds ( DPK) is the main source of bank loans. The credit comes from an Italian word 'credere' which meansconfidence. It refers to the confidence of creditors that debtors will repay the loan with interest in accordance with the agreement of both parties.Furthermore, according to Rivai (2006: 4), credit is the delivery of goods, services, or money from one party (creditor/or lender) on thebasis of trust to another party (the customer or debtor/borrower) with a promise to pay from the recipient credit to the lender on adate agreed upon by both parties.

Elements of Credit: Rivai (2006:6) proposes that credits are granted on the basis of trust that the provision of credit is a gift of trust. This means that the given achievement is believed to be returned by the recipient of the credit on the terms and conditions which have been agreed. Based on the above definitions, the elements of the loan are as follows:

a. The presence of the two parties, namely the lender (creditor) and credit recipients (customers). The relationship of the lender and recipient is a credit cooperative relationship of mutual benefit.

b. Lenders' trust to loan recipients based on the credit rating of credit recipients.

c. Approval, in the form of the agreement with the bankwhich promises to pay the other party of the recipient credit to the lender. The promise to pay can be verbal, written (credit agreement) or in the form of the instrument (Credit Instrument).

d. The delivery of goods, services, or money from the lender to the loan recipients.

e. The element of time (time element). The element of time is an essential element of credit. No credit is given without the element of time, specially in terms of the lender and the views from the credit recipients. For example, savers give credit today for greater consumption in the future. Manufacturers require credits because of the time gap between production and consumption.

f. There is an element of risk (the degree of risk) on the part of lenders and at the receiving end credits. The risk on the part of the lenders is a risk of default (risk of default), either due to the failure of the business (commercial loans) or the inability to pay (consumer loans). The risk of fraud on the part of the customer is of the creditors, which includes the provision of loans originally intended by the lender to annex companies given credit or land as collateral.

g. The element of interest is acompensation (achievement) to the lender. For the lender, the interest consists of various components, such as the cost of capital, the general costs (overhead costs), risk premium, and so on. If the credit rating is high, premium riskscan be reduced by safety discount.

Types of Credit According to Casmir (2010: 103), the classification of credit types is shown to achieve a particular goal or objective to remember that every type of business has a variety of specific characteristics. In general, the types of loans disbursed by banks are as follows:

a. Viewed from the aspect of use: Credit intention in terms of usability is to look at the use of the money used in the main activity or just an extra activity.

b. Investment loan: loan that is usually used for business expansion or building projects/new factory, generally used for a relatively longer period and usually the usefulness of this credit is for the main activities of a company.

c. Working capital credit: the credit is used for the purpose of improving production operations. For example, the working capital loans granted to buy raw materials, pay wages or other costs associated with a manufacturing company. Working capital loans represent loans on credit thawed to support existing investments.

d. Viewed from the aspect of loan purposes: This type of credit is seen from the purpose of using a credit, whether it aims for returning cultivated or used for personal purposes. Types of credit in terms of objectives are as follows:

1) Credit Productive

2) Consumer Credit

3) Credit Trading 
e. Viewed from the aspect of period: In terms of time period, meaning the length of credit time, loans can be classified into:

1) Short-Term Loans

2) Medium-Term Loans

3) Long-Term Loans

f. Viewed from the aspect of guarantee: the guarantee means any provision of a credit facility to be protected with an item or marketable securities worth the minimum of loans. Types of credit in terms of the guarantee are as follows:

1) Loans with collateral

2) Loans without guarantee

Understanding mortgages According to the regulation of Bank Indonesia, housing loan is a credit facility granted by banks to individual customers who will buy or repair houses. In Indonesia, there are two types of mortgages:

a. Mortgage subsidy, that is a credit intended for middle and lower income people in order to meet the needs of housing or home improvements that have been owned.

b. Non mortgage subsidy, that is a mortgage intended for the whole community. Mortgage provisions are set by the bank, so that the determination of the amount of credit and interest rates are carried out according to the policy of the bank.

Customer Interests: According to Suryabrata (2002: 68), interest is "ataste more like and taste of interest in a matter or activity without being told". Interest is basically the acceptance of a relationship between the self with something outside the self. The stronger or nearer, the greater interest of the relationship. Interests can be interpreted as "the high tendency towards something, interested, attention, arousal and desire". Interest means the interest of a person against a good or service to be held or consumed. It also fits the theory of consumer behavior, which means the activity of individuals who are directly involved in obtaining and using goods or services, including a decision-making process in the preparation and determination of these activities. Interest is the tendency of a person's soul to something, usually accompanied by a feeling of pleasure. Interest does not arise suddenly; rather, it arises as a result of participation, experience and habits

Factors Affecting Customers' Interests in Choosing Bank Products and Services (Credit): Casmir (2010: 141) argues that with regard to a bank's product services, trust factor is the main weapon for attracting, influencing and maintaining loyalty. Therefore, the bank needs to pay attention to the following points:
a. The number of Bankers providing services to customers
b. The technology used in serving customers
c. A guarantee of the products / services rendered
d. Form of services rendered
e. Quality presented by bankers to customers in accordance with the expected capabilities

Factors Influencing Customers' Decisions in Taking Credit: Kotler (2005: 211) proposes that there are several factors that influence customers' decision to take credit, including:

a. Personal factors, which include age and life cycle stage, occupation, economic situation, lifestyle and income

b. Psychological factors, in which the psychological variables can be divided into needs (number of loans), motivation, perception, learning, beliefs and attitudes

c. Social factors, environmental factors around the customer which consist of a reference group and family

d. Factors of banks or financial institutions that offer credit to customers, include location, service, types of credit (loan), interest rate, term and loan procedure.

Factors Affecting Price (Interest): Casmir (2010: 137) argues that determining the size of the deposit rates and lending heavily are influenced by both, meaning that deposit and lending rates affect each other. Other factors that influence the price include the guarantee, term, government policy, and profit targets. The main factors that affect the size of the interest rate setting can be broadly described as follows : 

a. Needs Funds
b. Competition
c. Government policy
d. Desired Target Profit
e. Time period
f. Quality Assurance
g. The company's reputation
h. Products and Competitive
i. Good relationship
j. Third party guarantee

Other Factors Affecting the Determination of Interest Rate (Loan Pricing)Credit interest rates charged to customers are different from one customer to another, or between one client to another client.According to Siamat (2004: 128 ), the difference is caused by several considerations/factors, such as credit period, the adequacy and quality of the collateral, the sensitivity of the company (business segment ) on the competition in the company's reputation ( clients ), the guarantees of the third party relationship banks with customers and certainly consideration a source of funds to finance the project.

Figure 1: Conceptualization of the influence of Credit Period and Interest rate on the interest of home Ownership Credit Users in PT. PANIN Bank (PERSERO) TBK.

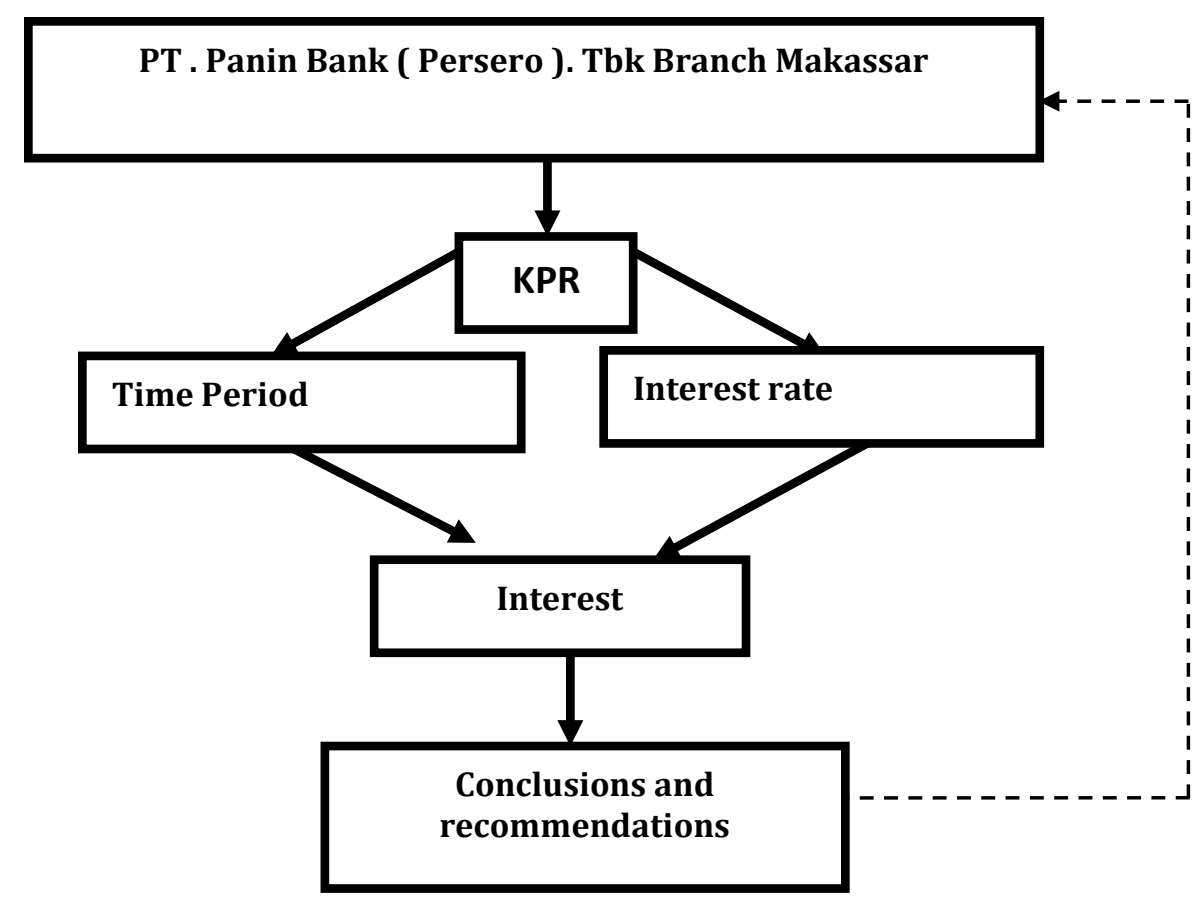

PT. Panin Bank ( Persero ) Tbk. Makassar is a branch of a conventional bank providing Housing Credit. To determine customers' interest, indicators that affect the interest of the customers should be taken into account. The indicators include credit period and interest rate.

From the analysis, the interest of borrowers to the mortgage offered by PT . Panin Bank ( Persero ) Tbk . Makassar branch can be examined.

\section{Methodology}

The variables used in this study consist of two (2) independent variables: Period (X1) and Interest (X2), with onedependent variable, namely Users'Mortgage Interest $(\mathrm{Y})$. 


\section{Operationalization of Variables :}

a. The mortgage stands for Housing Credit. Bank mortgage is one of the products offered to users who want to buy a house on credit at the bank, calculated in the rupiah unit.

b. Duration of the credit is one of the elements that isuseful for determining the interest rate to be determined by the bank.

c. The interest rate refers tothe interest rate of credit determined by the bank based on the interest rate securities of Bank Indonesia (SBI) which is calculated in terms of percent.

d. Interest is a feeling or motivation arising from an interest.

Analysis of data: The analytical methods used to analyze the data in this study are:

Statistical Methods:The calculations were done using data processing analysis techniques with SPSS version 20. In this case, the data processedwith SPSS is the formulation of multiple linear regression analysis,based on the relationship between the two (2) independent variables (duration and interest rate) with the dependent variable, which is the user's interestin KPR with the formula:

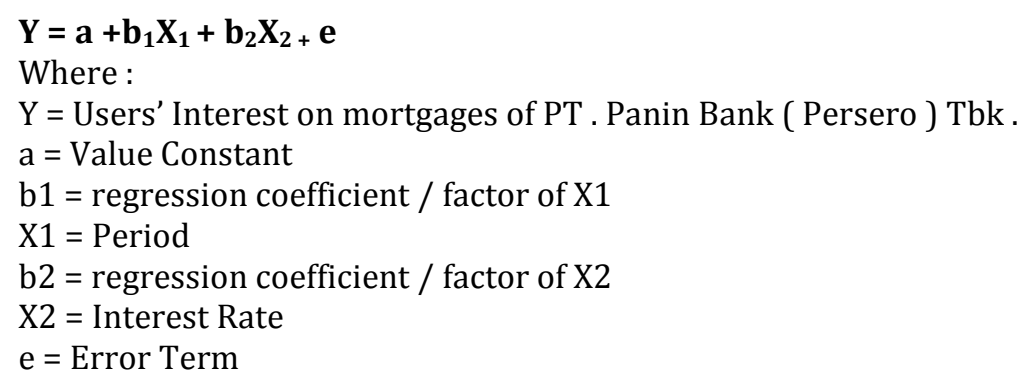

\section{Results and Discussion}

The population in this study includes customers who take mortgages from PT .PANIN Bank (PERSERO) TBK. Within the period of 2014, there are 4,213 customers. The samples in this study are restricted to customers of PT.PANIN Bank (PERSERO) TBK in 2014, as many as 100 customers. The distribution of respondents by sex is dominated by male respondents, $52.00 \%$ compared to $48.00 \%$ of female participants.

1. Test Instruments

a. Test Validity

Table 1: Validity of Test Results on Term Interest Rate

\begin{tabular}{lllll}
\hline No & $\begin{array}{l}\text { Indicator } \\
\text { Code }\end{array}$ & $\begin{array}{l}\text { Pearson } \\
\text { Correlation }\end{array}$ & R Standar & Result \\
\hline \multirow{2}{*}{ 1. Time Period } & $\mathrm{X} 1$ & 0,787 & 0,50 & Valid \\
$\left(\mathrm{X}_{1}\right)$ & $\mathrm{X} 2$ & 0,851 & 0,50 & Valid \\
& $\mathrm{X} 3$ & 0,745 & 0,50 & Valid \\
\multirow{2}{*}{ Interest rate } & $\mathrm{X} 4$ & 0,820 & 0,50 & Valid \\
$\left(\mathrm{X}_{2}\right)$ & $\mathrm{X} 5$ & 0,711 & 0,50 & Valid \\
& $\mathrm{X} 6$ & 0,672 & 0,50 & Valid \\
3. Users' interest & $\mathrm{Y} 1$ & 0,555 & 0,50 & Valid \\
mortgages $(\mathrm{Y})$ & $\mathrm{Y} 2$ & 0,607 & 0,50 & Valid \\
& $\mathrm{Y} 3$ & 0,823 & 0,50 & Valid \\
\hline
\end{tabular}

Source : processing results in 2015

Overall, the indicators of mortgages are influenced by interest rate; the validity of the test results showed that the questionnaire in this study can be said to be valid, because it has a range of corrected item total correlation that has been above 0.30 . 
b. Reliability Test: In this study, the realibility test was done by showing the value of Cronbach's Alpha. If the coefficient Cronbach's Alpha is greater than or equal to 0.60 , the instrument used as a measurement variable is realiable and vice versa.

Table 2: Test results Realibility

\begin{tabular}{lllll} 
No. & Variables & Cronbach's Alpha value & R Standard Value & Results \\
\hline 1 & Time Period (X1) & 0,894 & 0.60 & \\
2 & Interest rate (X2) & 0,858 & 0.60 & Realible \\
& User interest & & & Realible \\
3 & mortgages (Y) & 0,800 & 0.60 & Realible \\
\hline
\end{tabular}

Source : processing results in 2015

\section{Multiple Linear Regressions}

Table 3: Results of Multiple Linear Regression Coefficients Coefficient

\begin{tabular}{|c|c|c|c|c|c|}
\hline \multirow[t]{2}{*}{ Model } & \multicolumn{2}{|c|}{$\begin{array}{l}\text { Unstandardized } \\
\text { Coefficients }\end{array}$} & \multirow{2}{*}{$\begin{array}{l}\text { Standardized } \\
\text { Coefficients } \\
\text { Beta }\end{array}$} & \multirow[t]{2}{*}{$T$} & \multirow[t]{2}{*}{ Sig. } \\
\hline & B & Std. Error & & & \\
\hline (Constant) & 3.585 & .731 & & 4.903 & .000 \\
\hline Time Period & .307 & .127 & .326 & 2.416 & .018 \\
\hline Interest rate & .449 & .120 & .504 & 3.735 & .000 \\
\hline
\end{tabular}

a. Dependent Variable: user interest mortgages

Source: Results of Treatment SPSS 20.0

From the results of the data processing, the following regression equation is obtained:

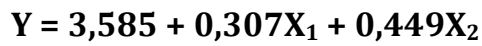

Meaning: $\quad \mathrm{X} 1=$ If $\mathrm{X} 1$ up 1 unit while $\mathrm{X} 2$ remains the value increased by 0.307 .

$\mathrm{X} 2=$ If $\mathrm{X} 2$ up 1 unit while the X1 remains then the value will increase by 0.449 .

From the above regression equation, a constant value of 3.585 is obtained. The dependent variable is positive because it has the value of the interest rate (X1) of 0.307 , a period (X2) of 0.449 . It means that the user's interest in mortgage is influenced by the term and interest rate. In other words, the meaning of the above equation is:

a. The constant $Y=3.585$, which means that if there is no variable duration and interest rates, the interest of the mortgage will remain the same.

b. X1 regression coefficient of 0.307 reflects that if the period rises, the user's interest in mortgages will increase, amounting to 0.307 vice versa. If the period declines, the interest in mortgages will decrease, amounting to 0.307 users.

c. X2 regression coefficient of 0.449 indicates that if the interest rate increases, the interest in mortgages will decrease, amounting to 0.449 users. On the other hand, if the interest rate decreases, the user's interest in mortgages will decrease, amounting to 0.449

Table 4: Determination Analysis Results Model Summary

\begin{tabular}{lllll}
\hline Model & $\mathbf{R}$ & R Square & $\begin{array}{l}\text { Adjusted } \\
\text { Square }\end{array}$ & $\begin{array}{l}\text { RStd. Error of the } \\
\text { Estimate }\end{array}$ \\
\hline 1 & $.810^{\mathrm{a}}$ & .656 & .649 & .833 \\
\hline
\end{tabular}

Predictors : ( Constant ), interest rate, term

Source : Results of Treatment SPSS 20.0 
Based on the table above, the contribution of the variable interest rate (X1) and period (X2) on user's interest in mortgages $(\mathrm{Y})$ can be seen from the determination. Based on the table above, which is at 0.649 showing that the magnitude of the contribution made by the independent variable time period ( X1 ) and interest rate ( X2 ) on the dependent variable user interest mortgages ( $\mathrm{Y}$ ) was $64.9 \%$. While the remaining $35.1 \%$ is influenced by other factors not examined. This means that the rate of change in the dependent variable is the mortgage interest ( $Y$ ), which can be explained by changes in the independent variable,the time period ( X1) and interest rate ( X2) amounted to $65.6 \%$. While the remaining $34.4 \%$ ( 1 - R2 ) is influenced by other factors not examined in this study .

3. Hypothesis Testing

a. t test

Table 5: Coefficients ${ }^{a}$

\begin{tabular}{lllll}
\hline Unstandardized Coefficients & $\begin{array}{l}\text { Standardized } \\
\text { Coefficients }\end{array}$ & T & Sig. \\
B & Std. Error & Beta & & \\
\hline 3.585 & .731 & & 4.903 & .000 \\
.307 & .127 & .326 & 2.416 & .018 \\
.449 & .120 & .504 & 3.735 & .000 \\
\hline
\end{tabular}

a. Dependent Variable: user interest mortgages

Source: Results of Treatment SPSS 20.0

To determine the value Ttable, the level of significance of $5 \%$ with degrees of freedom $d f=(n-k-1)$ is determined. If tcalculation $>\mathrm{Ttable}, \mathrm{Ho}$ is rejected and $\mathrm{Ha}$ is accepted and if $\mathrm{t}$ count $<\mathrm{T}$ table, then Ho is accepted and $\mathrm{Ha}$ is rejected.Table 4.5 shows that $\mathrm{T}$ calculation of coefficient variable time period (X1) of 2.416> 1.98 Ttable significant at $\alpha=5 \%$. Where $\alpha<0.05$ then Ho is rejected and Ha is accepted. If Tcalculation $>\mathrm{T}$ table, then Ho is rejected and Ha is accepted, meaning that the independent variable cannot explain the dependent variable and if $\mathrm{t}$ count $<\mathrm{T}$ table, then Ho is accepted and $\mathrm{Ha}$ is rejected, meaning that the independent variable cannot explain the dependent variable individually. This means that thevariable period doesnot individually affect the variable interest mortgage. $\mathbf{T}$ calculation coefficient variable interest rate (X2) of 3.735 1.98 Ttable significant at $\alpha=5 \%$, where $\alpha<0.05$ then Ho is rejected and Ha is accepted. This means the interest rate variable (X2) individually can affect the variable interest mortgage. Thus, the hypothesis that interest rates affect the interest of mortgage users can be accepted as true.

b. F Test

Tabel 6: ANOVA

\begin{tabular}{|c|c|c|c|c|c|}
\hline Model & Sum of Squares & Df & Mean Square & $\mathbf{F}$ & Sig. \\
\hline Regression & 128.302 & 2 & 64.151 & 92.520 & $.000^{\mathrm{b}}$ \\
\hline Residual & 67.258 & 97 & .693 & & \\
\hline Total & 195.560 & 99 & & & \\
\hline
\end{tabular}

a. Dependent Variable: user interest mortgages

b . Predictors : ( Constant) , interest rate, term

Source : Results of Treatment SPSS 20.0

$\mathrm{F}$ test is done to see how the variables of $\mathrm{X} 1$ and $\mathrm{X} 2$ simultaneously influence the dependent variable ( $\mathrm{Y}$ ) where $\mathrm{F}$ count $>\mathrm{F}$ table with a significant level of $<0.05$ or $5 \%$ thus the value Fcalculation $92.520>$ Ftable at 1.40 then the variable X1 (period) and X2 (the interest rate ) simultaneously y affect user's interest of mortgage.The objective to be achieved in this research is to determine how much the duration and interest rate influence mortgage users' interest in PT . Panin Bank ( Persero ) Tbk. Makassar branch. To meet these objectives, a study involving100 respondents has been conducted.After testing the duration ( X1 ) and interest rate (X2) on user's interest in mortgages ( $Y$ ) with a multiple linear regression, $t$ test , $F$ test , test the validity and reliability test, the result is discussed as follows :

Based on the multiple linear regression equation obtained from the data processing, variable constants obtained the value of 3.585, thevariable period of time ( X1) of 0.307 and the interest rate ( X2) of 0.449 . 
From the results of the equation, it could be said that the interest of users is affected by the mortgage terms and interest rates. Thus, the regression equation can be obtained as follows :

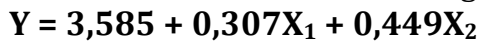

The regression equation shows a constant value of 3.585. Thevariable period of time (X1) and interest rate (X2) affect the interest of the mortgage users (Y), because it has a value of time period (X1) of 0.307 and the interest rate (X2) of 0.449 while the constant value of 3.585. From the calculation of multiple linear regression analysis, the magnitude of the contribution of independent variables or the time period (X1) and interest rate (X2) on user's interest in mortgages $(\mathrm{Y})$ are as follows:

a. The constant $Y=3.585$, which means that if there is no variable of interest rate and the term of the mortgage, the interest will remain the same.

b. X1 regression coefficient of 0.307 states that the rise of the period will increase user's interest in mortgages, amounting 0.307 vice versa. Thedecline of the period will lower the user's interest in mortgages amounting to 0.307 .

c. X2 regression of the coefficient of 0.449 states that the increase of the interest rate will lower the user's interest in mortgages amounting to 0.449 users and vice versa, the decrease of interest rate will increase user's interest in mortgages amounting to 0.449 .

The results of the reliability test of the instrument indicate that the entire instrument is reliable as a measurement of performance variables to influence user's interest in mortgages as presented in Table 4.2 which suggests that the variable declaration for the customer isquite reliablebecause the Cronbach's alpha for the period amounted to 0.894 , the interest rate 0.858 and for the interest of the mortgage by 0.800 .The $t$ test results showed that the time period (X1) and interest rate (X2) has no effect on user's interest in mortgages ( $\mathrm{Y}$ ) for a period of $\mathrm{t}$ count $=2.476, \mathrm{t}$ count interest rate $=3.735$ showed that $>1.98$. Thus, Ho is rejected and Ha is accepted. This shows that the independent variables of the time period (X1) and interest rate (X2) affectthe dependent variable of the user's mortgage interest $(\mathrm{Y})$.This discussion focuses on the analysis of the extent to which time period (X1) and interest rate (X2) affect the variable of users's mortgage interest in PT. Panin Bank (Persero) Tbk. Makassar branch. The long time period (X1) and lowinterest rate (X2) can increase the user'smortgageinterest inPT. Panin Bank (Persero) Tbk.

\section{Conclusion and Recommendations}

Based on the analysis and discussion presented in the previous sections, the following conclusions can be proposed:

a. With regard to the results of the analysis of the influence of time period and interest rates on user's interest in mortgages in PT. Panin Bank (Persero) Tbk. Makassar branch, it can be concluded that the term and interest rate have a positive effect on user's interest in mortgages. If the time limit increases, the interest of customers will also in crease, whereas if the interest rate increases, the interest of the customers will decrease.

b. Fromthe two variables researched, the most dominant variable affecting the mortgages user's interest in PT. Panin Bank (Persero) Tbk. Makassar branch is the interest rate, because interest rates have the greatest tcount compared to thetcount of period of time. It can be said that one of the most dominant variables affecting the interests of the mortgage user is the interest rate.

This research suggests the following point:

Based on the conclusions that have been stated previously, it is recommended thatthe bank pays more attention to the interest rate and the term of mortgage, because these two instruments greatly affect the interest of the mortgage users. 


\section{References}

Casmir (2010). Banks and Other Financial Institutions, Revised Edition, Jakarta; Raja Wali Press Book Citra Niaga College.

Kotler, P. (2005). Management Marketing, Jakarta: PT. Index Gramedia Group.

Melay, S. P. (2002). Basics of Banking, Moulds Second, Publisher: PT. Earth Literacy

Rivai, V. (2006). Credit Management Handbook: Theory, Concepts, Procedures, and Applications A Practical Guide Students, Bankers, and the Customer, Issue 1 Jakarta: PT. King Grafindo Persada.

Dahlan, S. (2004). Management of Financial Institutions, Edition Fourth, Publisher Institute of the University of Indonesia

Suryabrata, S. (2002). Educational Psychology, Jakarta: Hall Publisher FKUI

The Law No. 10 of 1998 about Banking

www.Bi.go.id

www.Panin.co.id 